\title{
Comparative DNA Analysis of Coconut (Cocos nucifera L.) palms with polyembryonic and monoembryonic origins
}

\author{
Daisy Jane A. Toting', Tessie C. Nuñez ${ }^{2 *}$ and Dilberto 0. Ferraren ${ }^{3}$
}

\begin{abstract}
Submitted: 6 August 2018 | Accepted: 09 June 2020

Makapuno is a rare, high-value coconut in the Philippines known for its extraordinary thick gelatinous meat with various uses in the food industry. Homozygous makapuno embryos do not germinate in vivo so plantlets are produced in vitro where one plantlet grows from an embryo. Rare cases of polyembryony were observed in makapuno hybrids developed by the Visayas State University. Knowledge of the genetic control of polyembryony may be used to increase the production of planting materials of these rare coconut types.

DNA analysis of two sets of twins (polyembryonic), three monoembryonic hybrid palms, and their monoembryonic parental cultivars Coconiño and tall makapuno was done using seven DNA primers to determine differences which may be associated with polyembryony in the hybrids. Polyacrylamide Gel Electrophoresis of PCR products showed DNA fragments amplified by primers CAC2 and CAC56 which are unique to the twins suggesting that polyembryony might have a genetic origin.
\end{abstract}

Keywords: Philippine Makapuno, Cocos nucifera L., polyembryony, twinning, DNA analysis

\section{INTRODUCTION}

Coconut (Cocos nucifera Linn) is reproduced through seeds or nuts. Each nut normally contains one embryo, which grows into a seedling one year after pollination. In some plants like citrus, development of more than one seedling from

'Department of Plant Breeding and Genetics, Visayas State University, Baybay City, Leyte, Philippines ${ }^{2}$ Varietal Improvement Section, National Coconut Research Center-Visayas, Visayas State University

${ }^{3}$ Department of Plant Breeding and Genetics, Visayas State University, Baybay City, Leyte, Philippines

*Corresponding Author. Address: Varietal Improvement Section, National Coconut Research CenterVisayas, Visayas State University; Email: tescnunez@gmail.com

DOI: 10.32945/atr4222.2020 
a seed, a phenomenon called polyembryony, regularly happens where the embryos may have sexual origin or somatic origin (Rodriguez et al 2004). Very rare cases of polyembryony have been reported in ordinary coconuts, but twinning was observed in rare mutant coconut (makapuno, VMAC) hybrids developed by the Visayas State University in Leyte, Philippines (Nuñez \& Ocoy 2008).

Makapuno, also known as 'coconut sport', is a rare mutant coconut first described in the Philippines. It is famous for its glutinous soft and thick meat. The meat was identified as the best source of galactomannan, protein, and virgin coconut oil (Rivera 2012). Limited planting materials is the most important problem in makapuno production in the country. Naturally occurring makapuno palms are heterozygous for the character with a maximum yield of $25 \%$, whereas the only possible means of producing higher-yielding homozygous palms through in vitro culture is costly and laborious. In vitro embryo culture produces only one plantlet from an embryo.

The origin of polyembryos in VMAC hybrids is not yet known and must be identified to understand its mechanism and its potential use to enhance the production of planting materials of rare varieties. As an initial step in understanding the origin of twin seedlings, the presence of molecular markers that may be linked with polyembryony in the VMAC hybrids was studied.

DNA-based molecular markers are multipurpose tools that are useful in various fields like taxonomy, plant breeding, and genetic engineering (Joshi et al 1999). Microsatellites or Simple Sequence Repeats (SSRs) are considered the most instructive polymorphic marker system among diverse DNA marker methods (Tautz \& Renz 1984, Powell et al 1996). Perera et al (1999) used eight pairs of simple sequence repeat (SSR) primers in analyzing the genetic diversity of different types of coconuts. Distinctions among 116 of the 130 individuals studied were observed. Seven of these primers were used in this study.

\section{MATERIALS AND METHODS}

\section{Coconut Materials Studied}

Three Coconino $x$ UPLB Tall Makapuno $\left(\mathrm{VMAC}_{1}\right)$ hybrid palms with monoembryonic origin (VNM1, VNM2, VNM3), two pairs of VMAC twins (Figure 1; $T 1 L$ and T1R as the first pair, and T2L and T2R as the second pair), and one representative monoembryonic palm of each parental variety Coconiño (CNO) and UPLB Tall Makapuno (UPM), were used as the sources of DNA studied. Leaflet samples were obtained from the youngest open leaf of each sample palm in VSU.

\section{DNA Extraction and Preparation}

Leaf samples from each palm were separately cut into three-centimeters-long pieces, weighed separately to about six grams each, and placed in separate polyethylene bags. The DNA was extracted from the leaf samples following the procedure described by Quimio et al (2001) and were kept in $-20^{\circ} \mathrm{C}$ storage prior to Polymerase Chain Reaction (PCR). 


\section{Comparative DNA Analysis of Coconut}

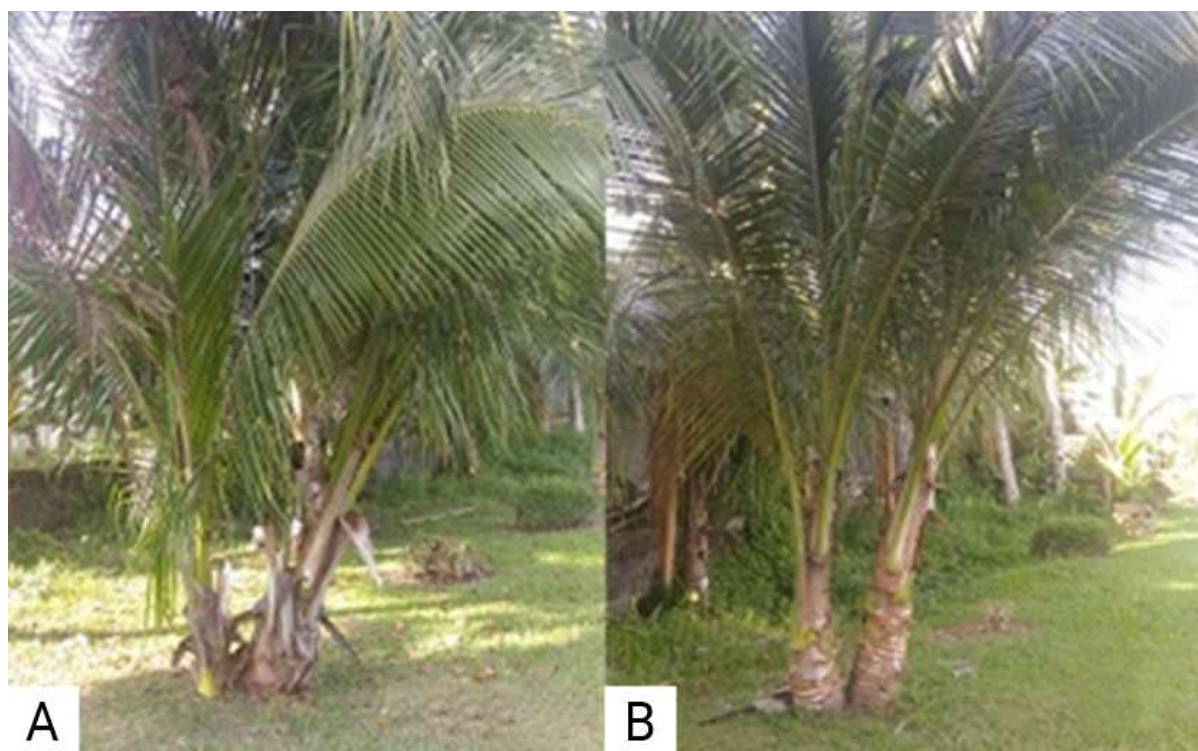

Figure 1. VMAC, palms with polyembryonic origin: (A) T1L (left) and T1R (right), and (B) T2L (left) and T2R (right)

\section{Primers and DNA Amplification}

Seven DNA primers were selected from the eight primers used by Perera et al (1999) (Table 1). CAC6 was excluded because it did not amplify VSU makapuno's DNA in a previous study by Lantaca (2016).

Table 1. Primers used for DNA amplification

\begin{tabular}{|c|c|c|c|}
\hline Locus & Repeat & Primers $\left(5^{\prime}-3^{\prime}\right)$ & $\begin{array}{l}\text { Size (bp) } \\
\text { Range }\end{array}$ \\
\hline CAC2 & $(\mathrm{CA})_{12}(\mathrm{AG})_{14}$ & $\begin{array}{l}\text { AGCTTTTTCATTGCTGGAAT } \\
\text { CCCCTCCAATACATTTTTCC }\end{array}$ & $210-254$ \\
\hline CAC3 & $(\mathrm{CA})_{13}$ & $\begin{array}{l}\text { GGCTCTCCAGCAGAGGCTTAC } \\
\text { GGGACACCAGAAAAAGCC }\end{array}$ & $187-203$ \\
\hline CAC4 & $(\mathrm{CA})_{19}(\mathrm{AG})_{17}$ & $\begin{array}{l}\text { CCCCTATGCATCAAAACAAG } \\
\text { CTCAGTGTCCGTCTTTGTCC }\end{array}$ & $182-216$ \\
\hline CAC8 & $(\mathrm{AG})_{10}(\mathrm{CA})_{9}$ & $\begin{array}{l}\text { ATCACCCCAATACAAGGACA } \\
\text { AATTCTATGGTCCACCCACA }\end{array}$ & $188-210$ \\
\hline CAC10 & $(\mathrm{TA})_{6} \mathrm{CATA}(\mathrm{CA})_{11}(\mathrm{TA})_{8}$ & $\begin{array}{l}\text { GGAACCTCTTTTGGGTTCATT } \\
\text { GATGGAAGGTGGTAATGCTG }\end{array}$ & $195-205$ \\
\hline CAC13 & $(\mathrm{CA})_{9}(\mathrm{TA})_{5} \mathrm{~A}(\mathrm{TA})_{4}(\mathrm{CA})_{6}$ & $\begin{array}{l}\text { GGGTTTTTTTAGATCTTCGGC } \\
\text { CTCAACAATCTGAAGCATCG }\end{array}$ & $158-172$ \\
\hline CAC56 & $(\mathrm{CA})_{14}$ & $\begin{array}{l}\text { ATTCTTTTGGCTTAAAACATG } \\
\text { TGATTTTACAGTTACAAGTTTGG }\end{array}$ & $144-168$ \\
\hline
\end{tabular}


DNA amplification was done by PCR using the selected primers after the optimization of the cocktail of chemicals and enzymes. The cocktail consisted of $15.65 \mu \mathrm{L}$ nuclease-free $\mathrm{H}_{2} \mathrm{O}$ and $1 \mu \mathrm{L}$ primer sequence, both forward and reversed, $1 \mu \mathrm{L}$ DNA template, $2.5 \mu \mathrm{L}$ Buffer $\mathrm{A}, 0.75 \mu \mathrm{L} \mathrm{MgCl}_{2}, 0.5 \mu \mathrm{L}$ dntp, $2.5 \mu \mathrm{L}$ Go Taq, and $0.1 \mu \mathrm{L} 2 \times 1000 \mathrm{uTaq}$ DNA Polymerase (Vivantis) with a total amount of $25 \mu \mathrm{L}$ per DNA sample. The thermocyclic condition described by Perera et al (1999) was applied by complete denaturing of the DNA samples at $94^{\circ} \mathrm{C}$ for three minutes, primer annealing at $65^{\circ} \mathrm{C}$ for one minute, followed by seven-step touchdown decreasing by $1^{\circ} \mathrm{C}$ at each step to $58^{\circ} \mathrm{C}$, and lastly, primer extension at $72^{\circ} \mathrm{C}$ for two minutes. After 27 cycles, conditions were $94^{\circ} \mathrm{C}$ for one minute, $58^{\circ} \mathrm{C}$ for one minute, and $72^{\circ} \mathrm{C}$ for two minutes.

\section{Agarose Gel Electrophoresis}

The PCR products were run in $1 \%$ agarose gel for an hour at 100 volts to separate DNA fragments according to their size. Nine microliters of each DNA sample was loaded in each lane. The DNA bands were observed in an Ultra Violet transilluminator.

\section{Polyacrylamide Gel Electrophoresis (PAGE)}

Ten microliters of each sample were poured in an assigned lane of previously prepared PAGE. It was run for $2 \mathrm{~h}$ and $35 \mathrm{~min}$. Staining was done with Gel Red. The gel was soaked for $30 \mathrm{~min}$ and viewed in the PhotoDoc Digi Transilluminator.

\section{RESULTS AND DISCUSSION}

\section{PCR Optimization}

The first primer used for the optimization of the PCR cocktail was CAC2. Good amplifications were observed in all DNA samples in a dilution ratio of $1: 2$ where $4 \mu \mathrm{L}$ DNA and $8 \mu \mathrm{L} \mathrm{ndH}_{2} \mathrm{O}$ were mixed together in order to obtain $12 \mu \mathrm{L}$ working DNA of each sample. The segment was about 300 base pairs (bp) and common among all samples (Figure 2).

Using the 1:2 dilution ratio, CAC3 was able to amplify clearly a segment of about $200 \mathrm{bp}$ in the DNA of CNO, the only non-makapuno among the palms studied, but no fragment in the makapuno genome was well-amplified. This amplified segment might be associated with normal meat endosperm. CAC4, CAC8, CAC10, CAC13, and CAC56 were able to amplify DNA fragments in all samples. The band size of CAC4, CAC8, and CAC10 products was between 200-300bp. CAC4 amplified fragments in T2L and T2R, which was similar to a band in UPM. This fragment was longer than the fragment amplified in CNO, T1L, T1R, and the three monoembryonic $\mathrm{VMAC}_{1}$ palms. Clear bands were also observed in PCR products of CAC8, CAC10, and CAC13. PCR products of CAC10 showed a unique band in DNA samples of CNO and T1R, which was about 1000-1200bp. This fragment, however, was absent in T1L, the twin of T1R. CAC13 had the best amplification among all primers because clear bands were developed in all samples. CAC13 products were between 100$150 \mathrm{bp}$. A band that is unique to UPM was developed. CAC56 amplified a DNA segment of about $200 \mathrm{bp}$ in all samples. 


\section{Comparative DNA Analysis of Coconut}
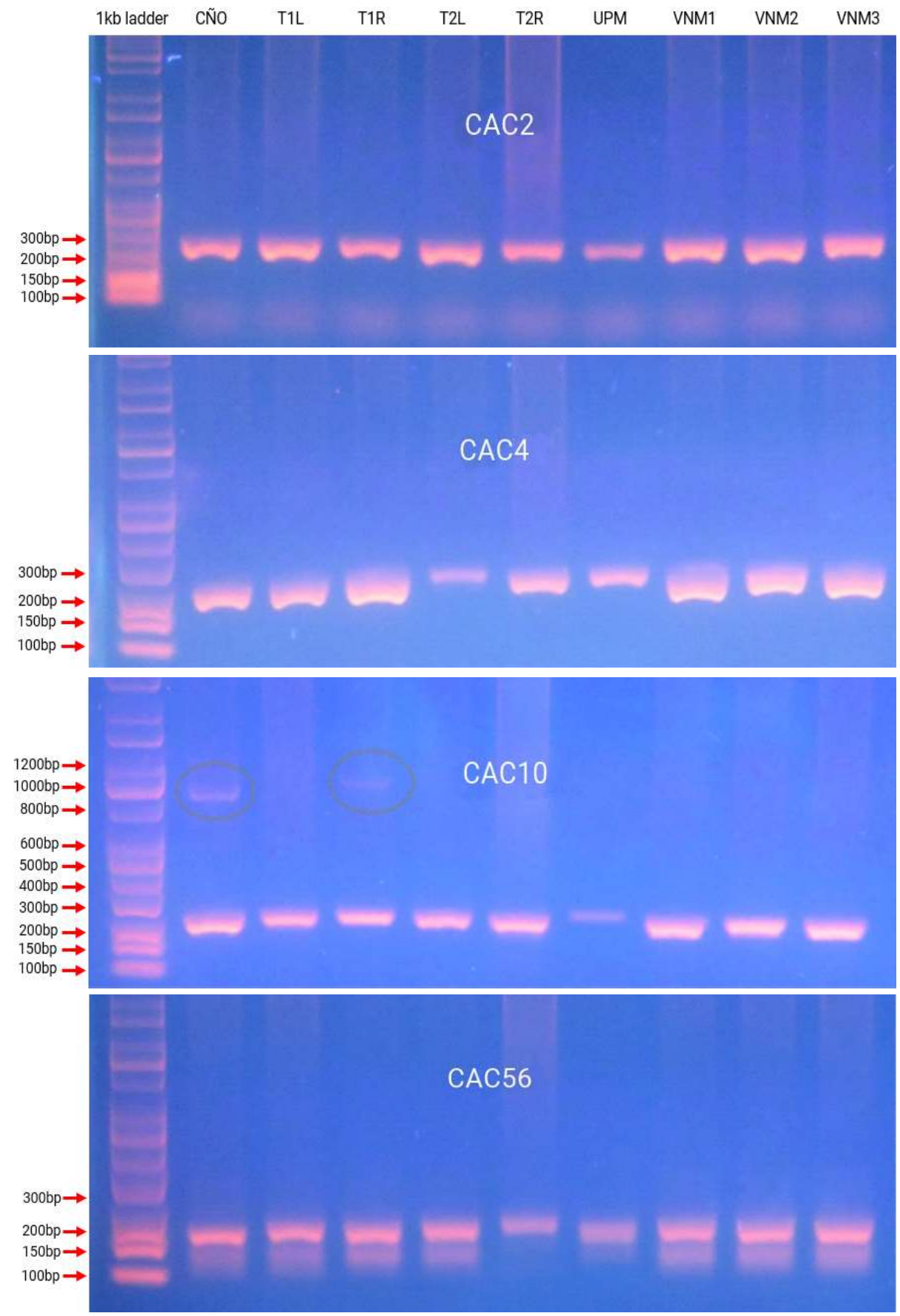

Figure 2. PCR amplified DNA segments of coconut palms with monoembryonic and polyembryonic origins 

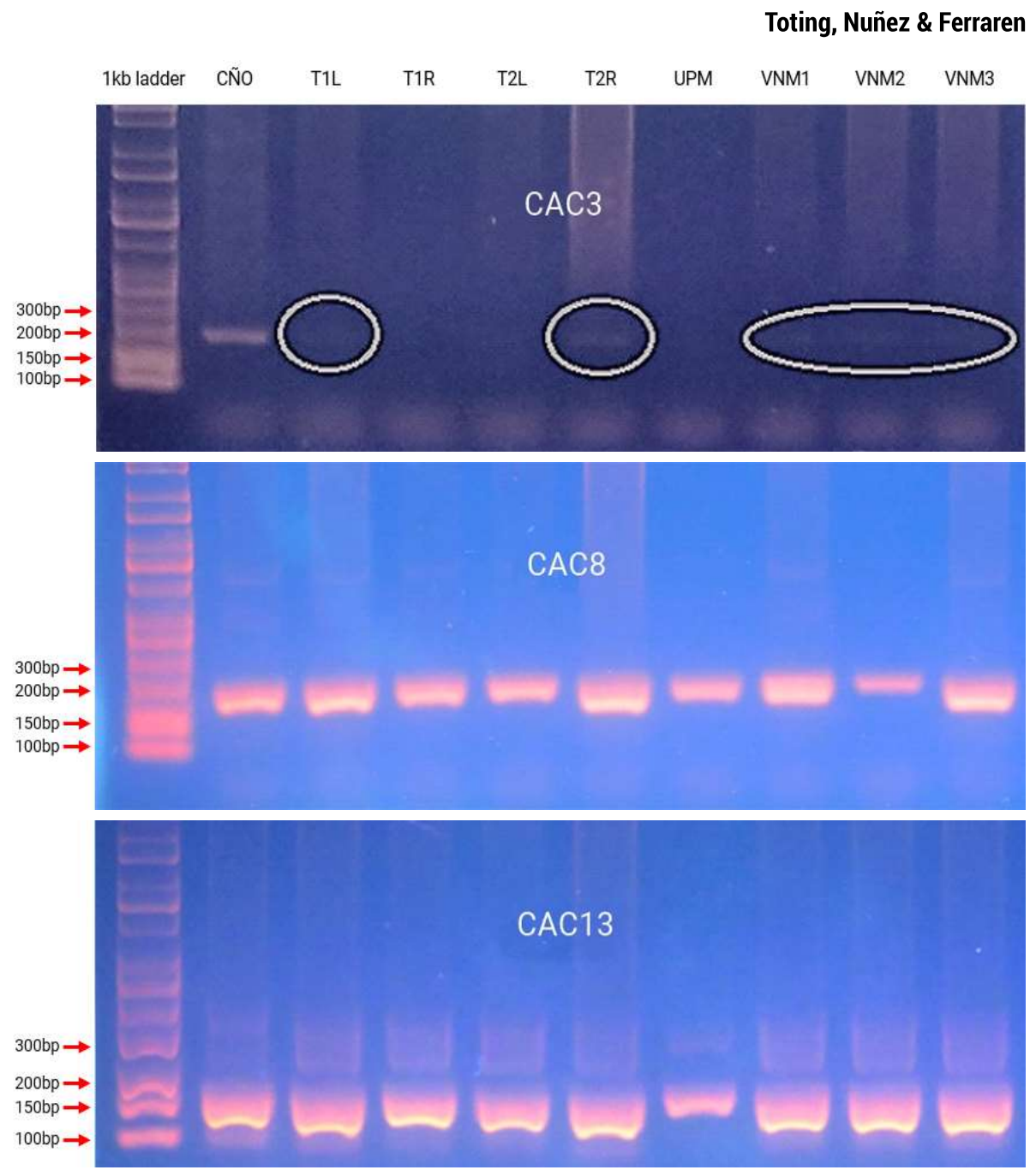

Figure 2 continued

In all primers except CAC8, the VMAC1 samples with monoembryonic origin had the same bands indicating a high degree of similarities in their genomes since they have the same parents. UPM had low amplification in all primers and is expected to be highly heterozygous except for the makapuno gene. The makapuno trait is expressed only in homozygous individuals because it is recessive (Zuñiga 1953).

\section{Polymorphism Detected by PAGE}

The PCR products of CAC2, CAC4, CAC8, CAC10, CAC13, and CAC56 were run in native PAGE. All primers were able to amplify unique bands (Figure 3 ). Two bands that were very close to each other were amplified by CAC2 in all samples except UPM. Moreover, CAC2 amplified a band that was unique only to T2L and T2R, which 


\section{Comparative DNA Analysis of Coconut}

was about 600bp indicating that the two samples are identical with respect to the amplified band. CAC2 also amplified three bands in samples T2L, T2R, and UPM, which were about 200-300bp. This pattern of bands was not found in the other samples. In a similar study by Lantaca (2016), the same bands were found in samples T2L and T2R suggesting further the possibility that the twins have identical genomes and that they might have originated from a single fertilization event of an egg cell by a sperm nucleus.

CAC4, CAC8, and CAC13 amplified two-fragment bands that were present only in $T 1 R$, which were about 300,400 , and $150 \mathrm{bp}$, respectively. This suggests that $\mathrm{T} 1 \mathrm{~L}$ and T1R may not be identical twins and might have developed from two different cells in the embryo sac, which were fertilized by two different pollen grains. Furthermore, T1L had very similar bands with CNO in most cases. Similar to the results in CAC2, CAC4 amplified short fragments of about 200bp in T2L, T2R, and UPM. CAC4 also showed a unique band that was absent in UPM yet present in the rest of the samples. This may be a marker linked to the dwarfism or the selfpollinating gene in CNO. Similar band patterns in products of primers CAC8, CAC10, and $\mathrm{CAC13}$, for all samples except UPM, could be associated with the traits inherited from CNO.

CAC56 amplified many unique bands. It amplified bands that are unique in T1R, T2L, and T2R. On the other hand, T1L had the same fragment found in CNO, VNM1, VNM2, and VNM3. This is the same observation reported by Lantaca (2016) wherein T1R, T2L, and T2R exhibited similar bands amplified by CAC2, which were absent in T1L, VNM1, VNM2, and VNM3. CAC56 also detected bands that are common in all $\mathrm{VMAC}_{1}$ hybrids as well as in UPM yet absent in CNO. One of these bands is more likely associated with the gene for makapuno. Results also showed similar bands of about 200-300bp, present in samples T2L, and T2R and absent in T1L, VNM1, VNM2, and VNM3, which could possibly be a marker associated with polyembryony.

\section{CONCLUSION}

The results of this study identified DNA primers, such as CAC2, CAC4, CAC8, CAC10, CAC13, and CAC56, which can amplify the genome of the Philippine makapuno and its hybrids. The study also showed polymorphism in the DNA samples studied and found bands that are unique to specific genotypes. A unique band found only and common in T2L and T2R may suggest that they are identical twins. Twinning might have come from the splitting of a single embryo into two during development resulting in genetically identical twins. Some differences in the genomes of T1L and T1R may indicate that they are not identical twins and might be products of two separate events of fertilization in the same embryo sac resulting in twins that are not genetically identical. Further studies are needed to verify and use the results presented in this paper, which could eventually lead to the identification of the gene for polyembryony in coconut. 